\title{
Mission Unaccomplished: Impediments to Affordable Housing Drive in Addressing Homelessness in Sub-Saharan Africa
}

\author{
Emeka Emmanuel Obioha
}

Department of Social Sciences, Walter Sisulu University, Mthatha 5117, South Africa; emekaobioha@gmail.com

\begin{abstract}
Affordable housing is a people-centered strategy in dealing with homelessness. However, the increasing number of people in need of homes in sub-Saharan Africa suggests that this strategy has not afforded homes to the homeless. Theoretically, affordable housing exists to provide cheap and decent homes, but in contrast, these social houses are practically unaffordable, which raises the question of why this is the case. This paper articulates the impediments that account for unrealized affordable social housing in sub-Saharan Africa. It argues that tackling these impediments through the recommended ways will booster realization of this dream. In conclusion, while provision of affordable housing to all who are in need of homes in various countries in sub-Saharan Africa is a desirable goal, all indications point to the reality that this mission is far from an accomplished status.
\end{abstract}

Keywords: homelessness; affordable housing; challenges; Sub-Saharan Africa

Citation: Obioha, Emeka Emmanuel. 2021. Mission Unaccomplished: Impediments to Affordable Housing Drive in Addressing Homelessness in Sub-Saharan Africa. Social Sciences 10: 310. https://doi.org/10.3390/ socsci10080310

Academic Editor: Nigel Parton

Received: 20 June 2021

Accepted: 13 August 2021

Published: 17 August 2021

Publisher's Note: MDPI stays neutral with regard to jurisdictional claims in published maps and institutional affiliations.

Copyright: (C) 2021 by the author. Licensee MDPI, Basel, Switzerland. This article is an open access article distributed under the terms and conditions of the Creative Commons Attribution (CC BY) license (https:/ / creativecommons.org/licenses/by/ $4.0 /)$.

\section{Introduction}

African countries are currently facing different economic, social and political challenges that directly and indirectly affect the living standard and welfare of their citizens. Prominent among these are the plethora of poverty, unemployment, conflicts and declining economy. Due to these realities, there is a struggle in meeting the basic human needs, namely food, clothing and shelter in accordance with globally acceptable ideal standards of living. Housing (shelter) has received more attention than any other need because of its importance in the health and security of citizens. Its importance as a basic human right is enshrined in Article 25 (1) of the Universal Declaration of Human Rights, which is also contained and domesticated in various UN member states' constitutions, including sub-Saharan African countries. This declaration provides that "everyone has the right to a standard of living adequate for the health and well-being of himself and his family, including food, clothing, housing, medical care and necessary social services" (United Nations 1948, Article 25). In the sub-continent, the constitutionality of housing as a basic human right derives more effect from nationally designed instrument such as the South African Freedom Charter (Obioha 2019). A few will dispute that "the developmental character of the state in South Africa is established in the 1996 Constitution's section on basic rights" which provided for a range of "socio-economic rights" (Pottie 2004, p. 607) that include the right of access to adequate housing. This right, which is recognized globally, is given effect and domesticated in most African countries, although at different rates.

The importance of shelter to human survival in pre-historic times and continuously to the present cannot be underestimated. Globally, housing remains one of the unmet needs of citizens in various countries, as shortages of housing becomes a reality, even in some developing countries. Evidence from Australia, for instance, showed that "in the last two decades, accessing affordable housing has been a major challenge for a substantial proportion of Australian households due to increases in house prices far outstripping increases in income" (Morris 2021, p. 23). While targets are set and strategic road maps are designed to meet the increasing demand for affordable housing in various countries, what is found in some subSaharan African countries seems to suggest that provision of affordable public houses is not 
yet a priority item of governments and leaders of these countries. This manifests in the huge number of citizens sleeping under bridges, on the streets and in inhabitable abodes, mainly in major cities and towns in the continent, as evinced in Alake's (2018) case of Lagos, which is similar to what exists in other major cities in the sub-continent, including Johannesburg, Cape Town, Nairobi, Durban and Addis Ababa, to mention but a few. There is, therefore, no doubt that homelessness is a stack reality and a problem that needs urgent attention and solution. The World Bank information on the state of the global urban population paints an accurate picture of the depth of the housing crisis in the sub-continent. In 2018, while a global estimate of the urban population that lived in slums and inhabitable abodes was 29.2\%, the sub-Saharan African estimate was 53.6\% (World Bank 2018). The depth of the housing crisis and direness of housing need manifests in the huge housing backlog of about 51 million units in the continent (Bah et al. 2018, p. 5). Within and across sub-Saharan Africa, there are over 45 million backlogged units (Appendix A). Even though the situation differs across countries and regions in the sub-continent, overall, 15 countries in sub-Saharan Africa have a housing backlog of over 1 million units each, whereas Nigeria accounts for the highest number of over 17 million, while the Democratic Republic of Congo and Tanzania sit on housing gaps of over 3 million units apiece (Bah et al. 2018).

Documented empirical evidence from across the economic blocs (West, East and Southern Africa, for example) presents a more vivid picture of a country-wise problem, where numbers keep increasing both in absolute figures, proportions and diversity of characteristics. In the West and Central Africa area, more than 380,000 people need shelter in the Cameroon Republic (Relief Web / (UNOCHA UN)), while 39\% (5.5 million out of 14 million) of Ghana's urban population need houses (Africa Research Institute 2016). In Ivory Coast, an estimate of $56 \%$ of the population live in slums (World Bank 2018), which suggests that homelessness is rife in the country. This is similar to the situation in Mali, where an estimated $80 \%$ of the population lack adequate housing (Racelma 2012), while more than 500 children live on the streets in Bamako, the capital city (South World 2018). Nigeria presents a worrying situation as there are over 24.4 million homeless people countrywide (UNCHR 2008), with 70\% of the Lagos population living in informal housing or are homeless (Cunningham 2017). In $2015,43.3 \%$ of the Guinean urban population lived in slums and were descriptively homeless (United Nations /Department of Social and Economic Affairs 2015), whereas in addition to over 100,000 homeless people in Lomé (Harambee 2019), 51\% of Togo's urban population (United Nations /Department of Social and Economic Affairs 2015) and 65\% of Monrovian urban residents in Liberia (Open DRI 2018) can be described as people without "houses" and therefore live in the same predicament.

The context in Eastern and Southern Africa is not different from the countries in the West and Central region of the sub-continent. In 2012, about 2 million Kenyans were homeless, with a projection of an annual increase of over 200,000 (Mercy Initiative for Africa (MIFA)). In Namibia, for example, 34\% of the urban population live in slums (Relief Web 2004), while the situation in South Africa is worse. According to Deutsche Welle (2019), there are 200,000 homeless people living on the streets of various cities and towns in the country. With a deficit of 1.6 million housing units, $66 \%$ of Ugandans live in inadequate housing (Habitat 2019); in Zambia, around 70\% of the urban population live in informal abodes (Mercy Initiative for Africa (MIFA)).

The United Nations' (2004) working definition of homelessness entails households or people without a shelter that would fall within the scope of living quarters. In characterization, "it varies from a situation where someone lives in open space, public space, on the street and other places that are not meant for human abode" (Obioha 2019, p. 1). However, due to the relativity of the concept, homelessness means different thing to different people. Unarguably, homelessness is a relative concept that needs contextual understanding, in which case, what constitutes homelessness in one culture may not mean the same in another culture, given the varied contexts of interpretation. In most cases, homelessness results from some or various situations that are both external and internal to individuals that experience it. While state and non-state actors most times ignore the internal and personal 
circumstances that drive homelessness, the emphasis has always been on the external or macro economically induced drivers, with corresponding macro social policies to control this social problem.

In curbing homelessness, sub-Saharan African countries apply different approaches at different times and for different reasons. In the past, some countries have applied criminalization and vagrancy laws to control homelessness, which was a common practice in apartheid South Africa (Killander 2019). Even more recently, through other municipal administration interventions (du Toit 2010), most governments in sub-Saharan Africa have taken the macroeconomic approach and therefore embarked on providing houses ${ }^{1}$ which can be classified as affordable housing or social housing in order to address homelessness in their countries. More importantly, by providing houses, countries appear to be dealing with only one out of numerous drivers of homelessness. Besides, while some perceive affordable housing as an effective mechanism in addressing homelessness, this assertion may not be generalizable for different population groups.

Theoretically, affordable housing initiatives exist to provide cheap but decent homes, specifically targeted at the poor citizenry. Unfortunately, the fact that there may be tracks of completed houses under social housing scheme in various cities that are not occupied, while there is a huge number of people in need of homes who cannot own them, suggests that affordable housing projects have not achieved the target of providing homes, especially the categories of homes that are within the economic means of the vast population of the needy in the sub-continent. One can argue that sub-Saharan African social housing, like in the Casa Propia case in Argentina, is such where "the contradiction the program represents is the failure to predict that better-off social groups would be the main beneficiaries of the projects" (Murillo 2001, p. 341). Given this prevailing ironical situation, where the intended target groups miss out, this paper argues that a number of obstacles hinder access to affordable housing schemes for the vast majority of people who need homes in various countries in the sub-continent. Based on the above, this paper articulates on the observed gap in affordable housing with non-commensurate rollout to accomplish the desired goal of ensuring that people in need of homes have roof over their heads. It deepens the argument, given that that there is "small scale of research in housing matters largely due to shortage of investment in research and development in many African countries" (Gbadegesin and Marais 2020, p. 488), especially on accomplishments in affordable housing schemes. Therefore, it is the mission of this paper to highlight the obstacles and provide recommendations to deal with the unaccomplished mission in order to boost affordable housing in the sub-continent.

\section{Materials and Methods}

The essence of this paper is to provide a broad overview of the situation of affordable housing in sub-Saharan Africa. The scope of this discourse and nature of information needed does not require any newly field generated empirical data. Based on the above, this paper relied mainly on published secondary sources in advancing arguments on the impediments to affordable housing in sub-Saharan Africa. These secondary sources include articles in scientific journals, private sector corporations, periodicals, government and intergovernmental organization data sources, such as the World Bank, United Nations bodies, and state statistical fact sheets. The researcher randomly extracted relevant information from selected target sources according to the needs and purpose through a desk research approach. The researcher applied a content analysis approach to analyze data collected from various sources.

\section{Rationalizing and Contextualizing Affordable Housing in Sub-Saharan Africa}

\subsection{Understanding What Is Affordable Housing}

Affordable housing is one out of many strategies that governments have put in place to deal with homelessness in sub-Saharan Africa. According to UNHabitat (2011), affordable housing is housing which is adequate in quality and location and does not cost so much 
that it prohibits its occupants from meeting other basic living costs or threatens their enjoyment of basic human rights. More importantly, such houses should form part of a household total expenditure, but not all of it. In addition, such housing units should be located within the reach of a majority of a country's population. The economic point of view considers purchase and maintenance costs as two important elements in determining the affordability of a house. Therefore, a house must neither be too expensive to procure nor to maintain but also close to basic amenities, as pointed out by the World Economic Forum. "This goes beyond meeting expenses related to operations and maintenance; it also involves considerations of transport, infrastructure and services. If a house is cheap enough to buy and run, but located far from livelihood opportunities or amenities such as schools, it cannot be said to be affordable" (World Economic Forum 2019, p. 10).

Affordability of housing can be determined through three distinct modalities, which include the Median Multiple, Hosing Cost Burden and Residual Income Methods (Su Ling and Almeida 2016; World Economic Forum 2019). However, the conception and reality of affordable housing may differ across geographies and regions. For instance, what people in the United Kingdom regard as an affordable house may not be so in any sub-Saharan African country, given the marked difference in economy, wellbeing, quality of life and standard of living. Even in the sub-Saharan African sub-continent and across independent countries, there is no uniform standard price index to measure housing affordability because these countries are at different economic standards.

\subsection{How Affordable Is "Affordable Housing" in Sub-Saharan Africa?}

Affordability of housing in the cities of developing economies including sub-Saharan Africa is a huge problem and housing is found to be $28 \%$ significantly less affordable compared to the cities in developed world, in terms of median affordability (Kallergis et al. 2018). Taking into cognizance that "affordable housing" is a relative concept, the question of "how affordable is affordable housing" can only be addressed by considering specific social and economic contexts. What is affordable in one country may not be affordable in another and even within the same country because housing affordability is also a function of demographic diversity, among others. In reality, most so-called affordable housing in subSaharan Africa is not affordable considering the supposed target population. A house can only be affordable in Nigeria, Kenya, Ethiopia or South Africa, for instance, or elsewhere in the sub-continent, if the prevailing minimum wage in such country is enough to purchase and maintain such house, within one-fourth of average income. In the sub-continent, affordability has become a major cause for concern as available evidence suggests that there is hardly any house provided through public or private housing schemes or socalled affordable housing that is affordable. Relevant indicators from selected countries in sub-Saharan Africa (Table 1) support this claim.

Based on the data, it is both mathematically and practically impossible for a minimum wage earner in the government sector to afford the cheapest house in the urban area in all the four countries listed. Unfortunately, it will take 8 years, 11 years, 24 years and 118 years for minimum wage earners in Nigeria, South Africa, Kenya and Ethiopia, respectively, to save up their whole income to be able to purchase the cheapest house in the country. The scenario is one of impossibility, given the number of years is worst in Ethiopia compared to other countries in the table and the fact that about 4 out of every 100 households can afford to own a home through mortgage finance. These wages are, therefore, far below the standard living income in these countries. In the city of Lagos, Nigeria, for instance, where the minimum annual rental fees for a decent house or apartment is between NGN 150,000 and NGN 250,000 (Alake 2018), the whole minimum wage earned can barely meet this rental fee. This leaves an average household with less than $10 \%$ of the total annual earning for other needs. As a result, the minimum wages earned are not enough to cover basic recurrent living needs such as food and clothing, let alone having enough to purchase house or enter into mortgage bond. Rarely, the recipients may be able to afford minimum house rental only. The situation is somewhat worse than depicted because wages are far 
lower in the private sector of these economies which employs a majority of the working class compared to the government-regulated sector. Conclusively, the housing affordability situation in the selected countries, therefore, exemplifies what is found in most, if not all, countries in sub-Saharan Africa. It is evident that affordable housing schemes have not provided houses that are cheap enough for low income and working-class people to afford within their financial means. With minimum wage, most citizens of sub-Saharan African countries cannot afford the cheapest house in their lifetime.

Table 1. Minimum wage and housing affordability pricing.

\begin{tabular}{|c|c|c|c|c|c|c|}
\hline Country & Population & Urban Rate & $\begin{array}{c}\text { Cost of Cheapest } \\
\text { New House }\end{array}$ & $\begin{array}{c}\text { Urban } \\
\text { Household That } \\
\text { Could Afford } \\
\text { with Finance }\end{array}$ & $\begin{array}{l}\text { Minimum Wage in } \\
\text { the Country } \\
\text { (Annum) }\end{array}$ & $\begin{array}{l}\text { Number of } \\
\text { Years to Save } \\
\text { for House }\end{array}$ \\
\hline Nigeria & $195,874,740$ & $4.24 \%$ & $\begin{array}{l}\text { NGN 2,900,000 } \\
\text { (USD 8056) }\end{array}$ & $26.95 \%$ & $\begin{array}{l}\text { NGN 360,000 } \\
\text { (USD 1000) }\end{array}$ & 8 Years \\
\hline Ethiopia & $109,224,599$ & $4.83 \%$ & $\begin{array}{c}\text { ETB 600,000 } \\
\text { (USD 20,548) }\end{array}$ & $0.42 \%$ & $\begin{array}{l}\text { ETB 5040 } \\
\text { (USD 173) }\end{array}$ & 118 Years \\
\hline Kenya & $51,393,000$ & $4.05 \%$ & $\begin{array}{l}\text { KES 4,000,000 } \\
\text { (USD 39,254) }\end{array}$ & $11.36 \%$ & $\begin{array}{c}\text { KES 162,864 } \\
\text { (USD 1598) }\end{array}$ & 24 Years \\
\hline $\begin{array}{l}\text { South } \\
\text { Africa }\end{array}$ & $57,779,422$ & $2.12 \%$ & $\begin{array}{l}\text { ZAR 436,000 } \\
\text { (USD 30,194) }\end{array}$ & $20.4 \%$ & $\begin{array}{l}\text { ZAR 38,000 } \\
\text { (USD 2632) }\end{array}$ & 11 Years \\
\hline
\end{tabular}

Source: Adapted from https: / / www.cgidd.com/ C-GIDD 2019 (accessed 5 April 2021) (Centre for Affordable Housing Finance in Africa 2019a). Note: The amounts in bracket are standardized United State Dollars equivalent, which are calculated from the average US dollar exchange value to the local currency in $2019^{3}$, according to Exchange Rates UK (2021a, 2021b, 2021c, 2021d).

\subsection{Why the Need for "Affordable Housing" in Sub-Saharan Africa?}

The question of whether there is any need for affordable housing sub-Saharan Africa is too simplistic with an obvious answer, because affordable social housing has been the response to homelessness and shortage of homes elsewhere in the world. In Australia, for instance, the government of the City of Sydney responded to the high cost of accommodation by providing affordable housing through a 7.5\% target set to be realized in the year 2030 (Morris 2021). In Africa, affordable housing is extremely a necessity as an estimate has shown that half of the population live in substandard conditions (Florida 2017), which are characterized by ruin, dilapidation, griminess and pollution. There is obvious need for affordable housing in sub-Saharan Africa, given various circumstances and contexts in many countries, where inadequate housing and homelessness are a huge challenge. Currently, in sub-Saharan African countries, the figures on the growing number of homeless people in the subcontinent is alarming. The Internal Displacement Monitoring Centre (2019) captured evidence from Ghana where thousands of people who live in unregulated space around rail lines are continuously facing eviction, coupled with about 55,000 and 79,000 people in the Old Fadama area, Ghana's biggest slum, who also lack security of tenure. In the same vein, according to Open DRI (2018), in Monrovia, Liberia, only about a quarter of the city population lives in planned areas, the remaining areas are unplanned slum neighborhoods, with $90 \%$ of the area and the people vulnerable to river and sea flooding. Undeniably, circumstances, including political, economic and even environmental conditions dictate that there is indeed an urgent need for countries to embark on sustainable affordable housing to address the twin conditions of homelessness and inadequate housing.

As evinced in Obioha (2020), total and real population growth is on the rise in most countries due to fertility growth. Wars and conflicts displace millions of people; the rate of urbanization is increasing and projected to increase further. Moreover, the percentage of people projected to live in cities in the near future is high, the percentage of city dwellers who live in slums is high, unemployment is increasing across various social categories, climate change and consequent natural disasters are severe as more people are on the peril of destruction, real income is on a steady decline and countries are facing serious economic challenges, while eviction is on the rise. 


\subsection{Has "Affordable Housing" Addressed Homelessness in Sub-Saharan Africa?}

For its intent and purposes, affordable housing initiatives are supposed to address homelessness in the sub-continent of sub-Saharan Africa as theoretically envisaged. It may be misleading to assume that all categories of people in need of homes have been able to secure homes through "affordable housing" without taking a cursory look at the situation in the sub-continent. The proposition in this paper is that affordable housing misses the target near completely and never met nor addressed the homelessness situation in sub-Saharan African countries. If the scheme had been successful, there would not be an alarmingly long queue of people waiting to be provided with homes across the sub-continent. Conservative estimates show that the housing backlog in the continent accounts for about 51 million units (Bah et al. 2018, p. 5), whereas a further look at the sub-Saharan area of the continent reveals a huge housing backlog of over 45 million (Appendix A), which is a combination of figures from West/Central Africa and East and Southern Africa. While it may be theoretically correct to allude that affordable housing initiatives may make houses more affordable by increasing the supply in the market to meet demand, it is not true that the poor and "classic homeless" people have extensively benefitted from any affordable housing scheme. Basic requirements set for accessing affordable housing apparently are out of reach for the majority of citizens who need houses in the sub-continent due to the following exclusivist criteria:

- Prospective applicants must have the required cash to purchase and own the home;

- Evidence of ability to pay what is offered or provide evidence of regular and steady income for a given period (this varies, sometimes three months or more);

- Must provide an acceptable civic identity document;

- Provide an acceptable collateral for the mortgage (if required);

- Should be gainfully employed or gainfully self-employed with evidence of income;

- More appropriately, earn more than legislated country minimum wage to qualify for the threshold;

- Should be able to open and operate a bank account.

The basic criteria as set by granting governments have cast doubt on the motive and target population of affordable housing in various countries of the sub-continent. The main question, then, is-for who is affordable housing designed? On the other hand, what population category is the target of affordable housing? The diagnostics suggest that "affordable housing" is rather exclusive than inclusive, in practical terms, where the requirements are out of reach of those who do not have ample cash or regular, steady income. Similarly, those who lost their identity documents or are not registered in the country's population register do not have any valuable or requisite collateral, are not gainfully employed or self-employed, earn less than the legislated minimum wage and do not have bank account or are unable to open and operate such an account cannot own or acquire the so-called "affordable house".

Typically, most affordable housing projects, to some extent, address the problem of inadequate housing; overcrowding and indecent living abode and never catered for "classic homeless" people. Such houses termed "affordable" which are "unaffordable" due to prevailing economic circumstances in the countries usually benefit the working-class population, who already have houses or could afford to rent houses or apartments but need more descent and a planned environment to live. In 2018, the Sun Newspaper, in its editorial, reported about Nigeria, where most current so-called affordable houses are out of the reach of the homeless and the "shelter needy poor" population segment because of the huge sum of money required for deposit. Similarly, in South Africa, the government has invested in social housing, yet what is on ground confirms the proposition that affordable social housing efforts have not addressed homelessness, despite millions of houses already built under various schemes. This, in some part, is attributable to "inherited inequalities" of apartheid that had "established a complex and challenging context" (Pottie 2004, p. 606) under which basic needs, including housing, can be met in present South African dispensation. 
In essence, sub-Saharan African affordable housing being a case of missed targets in terms of not addressing homelessness because homes have not been provided to the neediest and "classic homeless" is a resonation of what was observed in Argentina by Murillo (2001) and in other developing regions of the world. Murillo, for example, depicted the affordable housing Casa Propia project in Argentina as representing a contradiction of what the public-private partnership intended to deliver to the low-income earner, rather than the better off who are benefitting from the housing. The interconnectedness of systems in the society presupposes that the fact that "affordable housing" has not sufficiently addressed homelessness in sub-Saharan Africa is not an isolated scenario, but a function of some obstacles and impediments identified in this paper. These impediments function both individually and collectively in creating difficulty for citizens to access houses.

\section{Impediments to Affordable Housing in Sub-Saharan Africa}

Available information points to the gaps and inadequacies of "affordable housing" in addressing homelessness in a number of countries in sub-Saharan Africa. In some parts, there is a target missing in terms of whom affordable housing stands to benefit, while in others, it is about qualifying criteria set for the beneficiaries. However, in order to find workable solutions to the problem, it is not enough to identify the problem only without getting to the root of why affordable housing has not delivered homes to the needy homeless in the sub-continent. Reviewing the obstacles that keep the poor and homeless from securing affordable houses will provide the answers to why affordable housing initiatives have failed to serve the intended target population. In sub-Saharan Africa, key impediments to affordable housing are either from the supply or demand side of the process. While supply side issues are difficulty from the providers' perspective, the demand side include challenges that prospective affordable housing recipients experience.

\subsection{Supply-Side Impediments to Affordable Housing}

In the sub-continent, one of the major obstacles to affordable housing is the cost of building materials. Building materials for house construction are both locally derived and imported products. These include cement, steel rods, paints, etc. Due to high costs of production, owing to poor input infrastructure such as electricity, locally manufactured building materials are usually expensive. Similarly, the imported materials are equally expensive due to the weak economy and exchange rate regimes that do not favor the local currencies. In some cases, where sourcing of building materials happens locally at lower costs, the unavailability of cheap land is usually a serious impediment. Globally, as noted by World Economic Forum, "land acquisition is perhaps the most important and complicated piece of the affordable housing puzzle. The process entails confirmation of ownership, a survey that defines the dimensions of the land to be acquired, determination of its fair market value and procurement through a fair process" (World Economic Forum 2019, p. 14). In sub-Saharan Africa, land scarcity and the process of acquiring land for public housing among other public infrastructure is not generally easy. While the process tends to be straightforward with little or no complications in some countries with stable Land Use policies and laws, as in Nigeria's Land Use Decree [Act] 1978, it is more complicated mainly in Southern Africa, especially in South Africa, where the land reform process is embattled with suspicions and resistance. According to Pottie (2004, p. 606), "given the physical and political segregation of apartheid, meeting the demand for housing has been a central development challenge since 1994" because the previous racial supremacist government established spatial distribution planning that still affects much of what occurs in planning in the present time. Land has been and is still a source of conflict in most countries in the sub-continent. Even where there appears to be no bottlenecks in land acquisition, the cost or price of obtaining land for any purpose is extremely high. Scarcity of land for affordable housing is worsened by climate change, which has rendered some landmasses uneconomical in the sub-continent, coupled with high population growth vis a vis available land, especially in urban areas and cities. 
Besides scarcity of land, even where there is land, the bureaucratic processes followed before construction begins are usually too lengthy and cumbersome. In most countries of the sub-continent, there are unstandardized and sometimes conflicting rules when it comes to public and even private housing. For private developers, securing land and the approval of relevant construction plans from relevant government authorities is a huge set back. In some countries, it takes an average of two to three years to obtain all required approvals before the commencement of housing projects or estates. These bottlenecks determine whether a settlement is legitimate or not. As Kumar (2016, p. 274) noted, "a significant part of urbanization in India is happening through unregulated or partly regulated trajectories", in which case "regulatory authorities have come to terms with" and tried to deal with the situation "on a piecemeal basis over a period of time". This situation is not different in most parts of sub-Saharan Africa, where the bureaucratic processes involved in urban planning have ironically led to urban slums as builders run out of patience.

In recent years, there have been high interest rates on home financing in some countries in the sub-continent. On this note, obtaining finance for affordable housing is still a big challenge in many countries. Finance organizations, including banks, are reluctant in proving funds to private housing developers. In Nigeria, for instance, property developers experience much difficulty in securing loans from commercial banks with little or no prospect of accessing loan at less than $28 \%$ (The Sun 2018). Most financers prefer providing finance to "rapid investments" that are of high yield within a short period, with little attention to prolonged investments such as housing, which usually take long tenor to recoup. Government housing cooperatives are also facing similar challenges in terms of borrowing money from domestic banks to finance public housing projects. In cases where housing projects are funded through either domestic or foreign financial houses, it comes with very high interest rate, which leads to an increase in overall cost of housing.

Where state social housing is involved, widespread corruption, mismanagement of fund and other forms of corruption in the government system, including nepotism among others, have negatively affected provision of affordable houses in all its stages. Government officials in the Public Works Department often face accusations of diverting some funds earmarked for public housing projects into personal coffers and involved in malpractices such as nepotism in awarding contracts and tenders. In addition, at the distribution phase, some corrupt practices are reasons for the huge number of deserving citizens who never received any affordable public housing unit. In South Africa, there are reported cases of fraud and manipulation in the distribution of public houses constructed by the Reconstruction and Development Program (RDP). Some desperate households that earn over and above a certain threshold circumvent and manipulate the outcome of the Means Test, which is the standard procedure to determine households that qualify for the RDP houses, through the assistance of some corrupt public official.

Unplanned demographic changes represent a huge obstacle in affordable housing schemes in sub-Saharan Africa. Generally, in terms of social housing provision inadequacies in Lagos, "the pace of urban growth is increasing, and there is an absence of supporting infrastructures" (Kasim 2018, p. 952). Demographic changes manifest in increasing household size, in-migration of diversity of people, including youth and working class and aging population, which may affect the demand for specific types of housing units, vis a vis standard houses that are provided by governments and private sectors in the affordable housing scheme. These changes do occur unexpectedly, thereby causing serious upset in the existing long-term plan for public housing. Whichever direction the demographic changes move towards, it presents planning challenges to affordable housing providers, especially where there is a huge mismatch between the type of houses that exist and the characteristics of the population. 


\subsection{Demand-Side Impediments to Affordable Housing}

There are conditions that affect citizens' affordability of public and private housing in sub-Saharan Africa. Information on the Southern African region (Table 2), for instance, indicates the reality of some of these obstacles, which include few mortgage providers, high mortgage interest rates and down payment conditions, among others. Down payment conditions attached to accessing affordable housing, irrespective of the financial circumstances of candidates, is a known obstacle in the sub-continent. This is usually a certain fraction of the mortgage bond amount, which a prospective owner pays before occupation is affected. This required amount of down payment varies across countries and regions in the sub-continent.

Currently, in Nigeria, the combination of Federal Mortgage Bank and Family Home Fund (FHF) structure requires that qualified borrowers must provide a down payment of $10 \%$ of the purchase price while the mortgage lender and FHF (Centre for Affordable Housing Finance in Africa 2019a) fund the balance of $90 \%$ and $50 \%$, respectively. In Southern Africa, the required down payment ranges from 25\% in Zimbabwe to $20 \%$ in Zambia, Angola and Mozambique, 15\% in Lesotho and 10\% in other countries in the region including South Africa and Botswana, while 0\% is required in Namibia (Centre for Affordable Housing Finance in Africa 2018). This situation is similar to what occurs in Australia, where a minimum of 13 years is required for workers to save for the required down payment on medium-prices homes (Gurran et al. 2018).

Unfortunately, for the individuals and households that may want to rent a house or apartment instead of owning due to locational considerations, among others, the rental fees are high and outstrip the average income of many households in cities and urban centers in sub-Saharan African countries. Alake (2018) argued that the high demand for houses in most cities is because of a number of factors has pushed rental fees far beyond minimum wage in cities such as Lagos, Nigeria. Similar situations are found in South Africa, where the monthly minimum wage of a household breadwinner is not sufficient to pay rental fees for a decent household apartment of two or three bedrooms.

Similarly, for those who may want to own their homes, there are few mortgage providers and high mortgage interest rates in the prevailing financial market. Interest rates on loans secured for affordable housing are generally high for many prospective homeowners to afford. Similar to the down payment requirement, mortgage interest rates are in the double digit in most countries. In the Southern Africa region, it ranges from 5.5\% in Mauritius to 36\% in Malawi in the year 2018 (Centre for Affordable Housing Finance in Africa 2018). Due to the risks associated with mortgage loans and long-term gestation periods that are unattractive to some financial institutions, few mortgage institutions can offer housing loans to deserving clients in the sub-continent. There is enough evidence to suggest that one of the issues strongly militating against mass housing for Nigerians is the lack of an adequate mortgage finance system (The Sun 2018) and in Southern Africa, where there are about 43 mortgage providers in Mozambique and only one provider in Seychelles. 
Table 2. Housing finance information in Southern Africa, 2018.

\begin{tabular}{|c|c|c|c|c|c|c|c|c|c|c|c|c|c|c|}
\hline & Angola & Botswana & DR Congo & Lesotho & Madagascar & Malawi & Mauritius & Mozambique & Namibia & Seychelles & South Africa & Eswatini & Zambia & Zimbabwe \\
\hline $\begin{array}{l}\text { Mortgage } \\
\text { providers }\end{array}$ & 5 & $\mathrm{n} / \mathrm{a}$ & 6 & 3 & $\mathrm{n} / \mathrm{a}$ & $\mathrm{n} / \mathrm{a}$ & 20 & 43 & $\mathrm{n} / \mathrm{a}$ & 1 & $\mathrm{n} / \mathrm{a}$ & $\mathrm{n} / \mathrm{a}$ & 9 & 17 \\
\hline $\begin{array}{l}\text { Estimated } \\
\text { mortgages }\end{array}$ & $\mathrm{n} / \mathrm{a}$ & 17,500 & $\mathrm{v}$ & $\mathrm{n} / \mathrm{a}$ & $\mathrm{n} / \mathrm{a}$ & $\mathrm{n} / \mathrm{a}$ & $\mathrm{n} / \mathrm{a}$ & 600 & $\mathrm{n} / \mathrm{a}$ & $\mathrm{n} / \mathrm{a}$ & $2,387,796$ & $\mathrm{n} / \mathrm{a}$ & $\mathrm{n} / \mathrm{a}$ & $\mathrm{n} / \mathrm{a}$ \\
\hline $\begin{array}{c}\text { Mortgage interest } \\
\text { rate }(\%)\end{array}$ & 25.64 & 8.42 & 14 & 11.87 & 19 & 36 & 5.50 & 30 & 11.50 & 7.9 & 10 & 8 & 31 & 12 \\
\hline Down payment (\%) & 20 & 10 & $\mathrm{n} / \mathrm{a}$ & 15 & $\mathrm{n} / \mathrm{a}$ & $\mathrm{n} / \mathrm{a}$ & 10 & 20 & 0 & 10 & 10 & $\mathrm{n} / \mathrm{a}$ & 20 & 25 \\
\hline $\begin{array}{l}\text { Mortgage term } \\
\text { (years) }\end{array}$ & 20 & 25 & 15 & 20 & 20 & 10 & 30 & 20 & 20 & 20 & 20 & $\mathrm{n} / \mathrm{a}$ & 20 & 25 \\
\hline
\end{tabular}

Source: Adapted from (Centre for Affordable Housing Finance in Africa 2018). 
Formalization of housing in terms of security of tenure presents another huge challenge for many public housing owners. In South Africa, the government has built over three million RDP houses since democracy, but CAHF's analysis of deeds office data indicates that only 1.9 million of these properties have been registered (Centre for Affordable Housing Finance in Africa 2019b), which causes many of them lack a title deed. The resultant effect of non-formalization and registration of houses is insecurity of tenure, which is detrimental to the welfare of the occupants. In some countries, the distribution and allocation of public housing is fraught with a number of irregularities and corrupt practices, both from public officials and prospective homeowners. These irregularities negatively affect the chances of poor and deserving citizens in their bid to own homes. This includes the manipulation of the Means Test. ${ }^{4}$ In other instances, there are allegations that public houses are available to those who already have comfortable homes. These include the middle class who have no need for such houses and instead use them as rental income-generating ventures. This is akin to the contradiction that affordable housing represents in sub-Saharan Africa and elsewhere in developing countries, as illustrated in Murillo's (2001) Casa Propia in Argentina.

There is also widespread poor quality of delivery of houses in the schemes. When completed, quality of houses delivered in public housing schemes are sometimes substandard in rating with inadequate supporting infrastructure. Unfortunately, the affordable housing providers supply low-quality houses on the excuse that they are cheap. As some social housing RDP units are sometimes in a state of dilapidation in South Africa, urban social housing provided by the Lagos state government in Nigeria is challenged with poor infrastructure facilities that are necessary for improved standard of living (Kasim 2018). Low-quality materials used do not stand the test of time and function. The quality of construction is too poor that some of the houses remain uninhabitable in a short or long time.

Furthermore, affordable housing units tend to lack capacity and fall short of needs of many families because of the size of the household, which may be large or composed of certain demographic characteristics and varieties. The basis for construction of public houses and other affordable houses is an approved government prescription, usually less than normal standard houses, as it is the case with RDP houses in South Africa. In this regard, there is usually no consideration for restrictions and requirements for the household size that may qualify for allocation. As it is the case in some developed countries, "apartments, condominiums, cooperatives and terraced housing typically offer less privacy and space than single-family stand-alone units, but have lower costs of maintenance" (World Economic Forum 2019, p. 9).

In consonance with lack of capacity, there is lack of choice in terms of variety of houses. Choice is a very important component in a household's decision to own or rent a house or an apartment. Households consider the size of house and preferable locations. However, in practice, beneficiaries of public affordable housing do not possess the power of choice in most cases. Even though public housing applicants have the privilege to indicate their preferable location, size of housing unit desired in accordance with the family size and characteristics, this information is rarely used or not at all in determining where a household is eventually provided with accommodation.

\section{Recommendations for Sustainable Affordable Housing in Sub-Saharan Africa}

The impediments and obstacles to affordable housing in sub-Saharan Africa are stark realities that require an urgent response in order to reposition the vision and mission of the laudable project to meet the target of proving enough homes to the needy. Emanating from the discussions in different sections of this paper, the governments of sub-Saharan African countries have many opportunities to change the situation by applying some or a combination of the following outlined recommendations. The appropriate levels at which the recommendations are realizable and responsible actors are given below (Table 3). 
Table 3. Recommendations, levels and responsible implementing actors.

\begin{tabular}{|c|c|c|}
\hline Recommendation & Levels & Actors \\
\hline $\begin{array}{l}\text { Progressive policies that will address difficulty in land } \\
\text { appropriation for public housing purposes. }\end{array}$ & National and Provincial & Government Agencies \\
\hline $\begin{array}{l}\text { Institute measures to regulate prices of building materials or } \\
\text { make them more affordable. }\end{array}$ & Local Government/Municipal & Government Agencies \\
\hline $\begin{array}{l}\text { Political will and good governance to end unnecessary } \\
\text { bureaucracies and corrupt practices at different stages of the } \\
\text { affordable housing delivery system. }\end{array}$ & National & Government Agencies \\
\hline $\begin{array}{l}\text { Broaden mortgage industry and encourage the industry } \\
\text { through tax incentives, grants and exemptions. }\end{array}$ & National & Government Agencies \\
\hline $\begin{array}{l}\text { Regulate the interest rate regime to make it more affordable } \\
\text { for the poor. }\end{array}$ & National & $\begin{array}{c}\text { Government Agencies/Central } \\
\text { Bank }\end{array}$ \\
\hline $\begin{array}{l}\text { Institute intervention measures to assist poor households } \\
\text { with interest free loans. }\end{array}$ & National, Provincial and Local & $\begin{array}{l}\text { Public and Private Financial } \\
\text { Institutions (Banks, etc.) }\end{array}$ \\
\hline Remove down payment method for all public houses. & National and Provincial & Government Housing Agency \\
\hline $\begin{array}{c}\text { Insistence on application of Means Tests to determine } \\
\text { qualification for social housing. }\end{array}$ & National, Provincial and Local & Government Housing Agency \\
\hline $\begin{array}{l}\text { Deal with security of tenure and title deeds issue by } \\
\text { ensuring that all homeowners receive title deeds. }\end{array}$ & National & $\begin{array}{l}\text { Government } \\
\text { Agencies-Housing } \\
\text { Department and Deed Office }\end{array}$ \\
\hline $\begin{array}{l}\text { Consider the choices of applicants in allocating houses, in } \\
\text { order to ensure that other affordability factors are in place. }\end{array}$ & National, Provincial and Local & Government Housing Agency \\
\hline $\begin{array}{c}\text { Strengthen government partnership with private sector who } \\
\text { are involved in housing projects. }\end{array}$ & National, Provincial and Local & $\begin{array}{c}\text { Government Agencies, Private } \\
\text { Business Sector }\end{array}$ \\
\hline $\begin{array}{c}\text { Strengthen partnership with international development } \\
\text { agencies in different ways (co-partnership funding of } \\
\text { projects, etc.). }\end{array}$ & National and Provincial & $\begin{array}{l}\text { Government Agencies, Private } \\
\text { Business/Financial Sector }\end{array}$ \\
\hline $\begin{array}{c}\text { Support research and production activities in providing } \\
\text { cheaper houses, especially through harnessing of cheaper } \\
\text { local resources. }\end{array}$ & National and Provincial & $\begin{array}{l}\text { Government Agencies, Research } \\
\text { Institutions and Universities }\end{array}$ \\
\hline $\begin{array}{l}\text { Regulate rental processes in order to protect households' } \\
\text { need of rented apartments or houses. }\end{array}$ & Provincial and Local & Government Agencies \\
\hline $\begin{array}{l}\text { Provide financial and capacity building support to housing } \\
\text { co-operative societies in various countries. }\end{array}$ & Provincial and Local & $\begin{array}{l}\text { Public Finance Institutes, } \\
\text { Private Organizations, } \\
\text { Non-Governmental } \\
\text { Organizations }\end{array}$ \\
\hline
\end{tabular}

\section{Conclusions}

Affordable housing remains one of the strategies aimed at ending homelessness in sub-Saharan Africa. It is clear from the discussions that sub-Saharan Africa needs viable affordable housing schemes. Presently, the cost of a standard housing unit has been on the rise in the sub-continent, while household income remains fixed or on the decline in some cases, which needs further scholarly investigation in terms of bridging the gap between the two. As observed, affordable housing in the sub-continent is practically unaffordable due to some highlighted obstacles. Obstacles emanating from both the supply and demand side account for the unaffordability of housing in most parts of sub-Saharan Africa. Unplanned demographic changes, scarcity of land, cost of building materials, bureaucracy, corruption and high interest rates on home financing also impede the supply of houses. On the other side, lack of choice, low capacity of the building design, insecurity of tenure, poor quality of delivery, high mortgage interest rates, high rental fees and down payment policies are some of the challenges faced by prospective homeowners. In conclusion, while provision of affordable housing to all who are in need of homes in various countries in sub-Saharan Africa is a desirable goal, all indications point to the reality that this mission is not yet accomplished. 


\section{Recommendations for Further Research}

This paper has provided practical and sustainable recommendations on what to do, the level of the implementation and the responsible actors that will lead the drive towards mitigating the identified impediments. However, it is pertinent also to provide a new direction for future and further research beyond the present study.

- Having considered some limitations of this discourse, in terms of depth and breadth which may not be accomplished simultaneously under this study, further study that focuses on owning and renting strategies for the homeless population on county by country basis is recommended.

Furthermore, given that the present study is a macro analysis of the current situation in the sub-continent, an in-depth, country-based outlook could not be specifically achieved. In this regard, a more regionalized or country-based study is recommended in furtherance of more in-depth analysis.

Funding: This research received no external funding.

Data Availability Statement: This paper did not analyze or report on any other data stored elsewhere. The data provided in this manuscript are from published secondary data sources in the public space. The relevant links to all the published secondary sources are available and included in respective reference list in the reference section.

Acknowledgments: The author thanks the MDPI team for the professional language editing support. The author acknowledges the Division for Inclusive Social Development of UNDESA, New York for an opportunity provided to present a working version of this manuscript in an expert group meeting.

Conflicts of Interest: The author declares no conflict of interest.

Appendix A. Housing Backlog in Sub-Saharan Africa (West/Central Africa and East/Southern Africa)

\begin{tabular}{cc}
\hline Country/Sub-Region & Housing Backlog \\
\hline WEST AND CENTRAL AFRICA & 50,000 \\
Benin & 100,000 \\
Burkina Faso & 82,000 \\
Cabo Verde & $1,200,000$ \\
Cameroon & $1,000,000$ \\
Central African Republic & 200,000 \\
Chad & 140,000 \\
Congo & 600,000 \\
Côte d'Ivoire & 200,000 \\
Gabon & $1,700,000$ \\
Ghana & 140,000 \\
Guinea & 200,000 \\
Liberia & 400,000 \\
Mali & 50,000 \\
Mauritania & 100,000 \\
Niger & $17,000,000$ \\
Nigeria & 125,000 \\
Senegal & 166,000 \\
Sierra Leone & 250,000 \\
Togo & $\mathbf{2 3 , 7 0 3 , 0 0 0}$ \\
TOTAL &
\end{tabular}




\begin{tabular}{cc}
\hline Country/Sub-Region & Housing Backlog \\
\hline EAST AND SOUTHERN AFRICA & $1,900,000$ \\
Angola & 0 \\
Botswana & 30,000 \\
Burundi & $3,000,000$ \\
Democratic Republic of the Congo & $1,000,000$ \\
Ethiopia & $2,000,000$ \\
Kenya & $2,000,000$ \\
Madagascar & 100,000 \\
Malawi & 20,000 \\
Mauritius & $2,000,000$ \\
Mozambique & 80,000 \\
Namibia & 109,000 \\
Rwanda & $2,300,000$ \\
South Africa & 20,000 \\
Swaziland & $3,000,000$ \\
Tanzania & $1,600,000$ \\
Uganda & $1,500,000$ \\
Zambia & $1,250,000$ \\
Zimbabwe & $21,909,000$ \\
TOTAL & $2018,0)$. \\
\hline
\end{tabular}

Source: Adapted from Housing Backlog and Urbanization in Africa in Bah et al. (2018, p. 6).

\section{Notes}

1 Affordable Housing Scheme is part of a many governments' initiative to provide low-cost housing to citizens, which may be subsidized and provided at a very low market rate but may not be allocated free of charge. Typically, housing is defined as affordable when it consumes no more than 30 percent of a household's income. Quite differently, "social housing includes housing that is provided and managed by the state (i.e., public housing) or that of non-profit entities such as housing associations and community housing providers" (Sisson and Rogers 2020). Houses that fall into this category are either highly subsidized by the government or allocated free of charge to deserving poor citizens who cannot afford to rent or buy homes at any market rate. While affordable housing is low income priced but not social, all social houses are treated as affordable.

21 USD = 360.0594 NGN (Exchange Rates UK 2021a); 1 USD = 29.2123 ETB (Exchange Rates UK 2021b); 1 USD = 101.9938 KES (Exchange Rates UK 2021c); 1 USD = 14.4496 ZAR (Exchange Rates UK 2021d).

31 USD = 360.0594 NGN (Exchange Rates UK 2021a); 1 USD = 29.2123 ETB (Exchange Rates UK 2021b); 1 USD = 101.9938 KES (Exchange Rates UK 2021c); 1 USD = 14.4496 ZAR (Exchange Rates UK 2021d).

4 Means Test refers to a process where the income of an applicant will be tested by matching the applicant's household income against the set threshold.

\section{References}

Africa Research Institute. 2016. Slum politics in Accra: Understanding Urban Ghana. Africa Research Institute. Available online: https:/ / www.africaresearchinstitute.org/newsite/event/slum-politics-in-accra-understanding-urban-ghana-launch/ (accessed on 25 January 2020).

Alake, Motolani. 2018. Homeless in Lagos: Nigerians are sleeping under the bridge. Pulse Nigeria. December 10. Available online: https:/ / www.pulse.ng/news/local/homeless-in-lagos-nigerians-are-sleeping-under-the-bridge/pt3hq82 (accessed on 5 April 2021).

Bah, El-hadj M., Issa Faye, and Zekebweliwai F. Geh. 2018. Housing Market Dynamics in Africa. London: Palgrave Macmillan.

Centre for Affordable Housing Finance in Africa. 2018. Housing Finance in Africa: A Review of Africa's Housing Finance Markets. October. Available online: http://housingfinanceafrica.org/app/uploads/2018_CAHF_YEARBOOK_final-compressed.pdf (accessed on 5 April 2021).

Centre for Affordable Housing Finance in Africa. 2019a. Housing Finance in Africa Yearbook, 10th ed. Available online: https: //housingfinanceafrica.org/resources/yearbook/ (accessed on 5 April 2021).

Centre for Affordable Housing Finance in Africa. 2019b. Press Release: South Africa's First Ever Block Chain-Based Property Register Pilot. Available online: https:/ / housingfinanceafrica.org/documents/press-release-south-africas-first-ever-blockchain-basedproperty-register-pilot/ (accessed on 5 April 2021).

Cunningham, Ann. 2017. Violent evictions, homelessness is the cost of Lagos, Nigeria's Megacity. CBC News. Available online: https:/ / www.cbc.ca/news/world/lagos-nigeria-megacity-1.4409032 (accessed on 25 January 2020). 
Deutsche Welle. 2019. South Africa: From the Ashes of Apartheid. Deutsche Welle. Available online: https://www.dw.com/en/southafrica-from-the-ashes-of-apartheid/a-48462055 (accessed on 25 January 2020).

du Toit, Jacques Louis. 2010. Local metropolitan government responses to homelessness in South Africa. Development Southern Africa 27: 111-28. [CrossRef]

Exchange Rates UK. 2021a. US Dollar to Nigerian Naira Spot Exchange Rates for 2019. Available online: https://www.exchangerates. org.uk/USD-NGN-spot-exchange-rates-history-2019.html\#: \{\}:text=Average\%20exchange\%20rate\%20in\%202019\%3A\%20360. 0594\%20NGN (accessed on 25 July 2021).

Exchange Rates UK. 2021b. US Dollar to Ethiopian Birr Spot Exchange Rates for 2019. Available online: https://www.exchangerates. org.uk/USD-ETB-spot-exchange-rates-history-2019.html (accessed on 25 July 2021).

Exchange Rates UK. 2021c. US Dollar to Kenyan Shilling Spot Exchange Rates for 2019. Available online: https:/ / www.exchangerates. org.uk/USD-KES-spot-exchange-rates-history-2019.html\#: \{\}:text=Average\%20exchange\%20rate\%20in\%202019\%3A\%20101. 9938\%20KES (accessed on 25 July 2021).

Exchange Rates UK. 2021d. US Dollar to South African Rand Spot Exchange Rates for 2019. Available online: https: / / www.exchangerates.org.uk/USD-ZAR-spot-exchange-rates-history-2019.html\#: \{\}:text=Currency\%20Menu\&text=This\%20 is $\% 20$ the $\% 20$ US $\% 20$ Dollar,rate $\% 20 \mathrm{in} \% 202019 \% 3 \mathrm{~A} \% 2014.4496 \% 20 \mathrm{ZAR}$ (accessed on 24 July 2021).

Florida, R. 2017. Anatomy of a Nimby. Available online: https:/ / www.citylab.com/equity/2017/02/california-land-use-housingaffordability/517320/ (accessed on 25 January 2020).

Gbadegesin, Job, and Lochner Marais. 2020. The state of housing policy research in Africa. International Journal of Housing Policy 20: 474-90. [CrossRef]

Gurran, Nicole, Peter Phibbs, Catherine Gilbert, and Yuting Zhang. 2018. Options to Improve Key Worker Access to Home Ownership. Available online: https://www.tmbank.com.au/ \{\}/media/community/news/pdf/2018/tmb-key-workerhousingaffordability-report-part-2.ashx (accessed on 10 February 2019).

Habitat. 2019. The Housing Need in Uganda. Available online: https:/ / www.habitat.org/where-we-build/uganda or http:/ / www. bnm.gov.my/files/publication/ar/en/2016/cp04_002_box.pdf (accessed on 25 January 2020).

Harambee. 2019. Social Reintegration of Homeless Children-Lomé, Togo. Roma: Segreteria Internazionale Harambee Africa International Onlus, Available online: https://www.harambee-africa.org/en/progetti/social-reintegration-of-homeless-children-lome-togo (accessed on 10 January 2020).

Internal Displacement Monitoring Centre. 2019. Ghana: Country Information. Geneva: IDMC, Available online: https:/ /www.internaldisplacement.org/countries/ghana (accessed on 25 January 2020).

Kallergis, Achilles, Shlomo Angel, Yang Liu, A. Blei, N. Sanchez, and Patrick Lamson-Hall. 2018. Housing Affordability in a Global Perspective. Working Paper WP18AK1. Available online: https://www.lincolninst.edu/sites/default/files/pubfiles/kallergis_ wp18ak1.pdf (accessed on 10 February 2019).

Kasim, Oluwasinaayomi Faith. 2018. Wellness and illness: The aftermath of urban mass housing in Lagos, Nigeria. Development in Practice 28: 952-63. [CrossRef]

Killander, Magnus. 2019. Criminalising homelessness and survival strategies through municipal by-laws: Colonial legacy and constitutionality. South African Journal on Human Rights 35: 70-93. [CrossRef]

Kumar, Mukul. 2016. Social normativity, housing, and urbanisation in an Indian city. Development in Practice 26: 794-807. [CrossRef]

Su Ling, Cheah, and Stefanie Joan Almeida. 2016. Demystifying the Affordable Housing Issue in Malaysia. Available online: https: // themalaysianreserve.com/2017/05/30/demystifying-affordable-housing-issue-in-malaysia/ (accessed on 11 February 2019).

Mercy Initiative for Africa (MIFA). 2021. Homelessness Statistics in Africa. Available online: https://www.mifacharity.org/founderscommitee (accessed on 24 July 2021).

Morris, Alan. 2021. An impossible task? Neoliberalism, the financialization of housing and the City of Sydney's endeavors to address its housing affordability crisis. International Journal of Housing Policy 21: 23-47. [CrossRef]

Murillo, Fernando. 2001. Private-public partnership, the compact city and social housing: Best practice for whom? Development in Practice 11: 336-43. [CrossRef]

Obioha, Emeka E. 2019. Addressing Homelessness through Public Works Programes in South Africa. Paper presented at the Expert Group Meeting on the Priority Theme: Affordable Housing and Social Protection Systems for all to Address Homelessness, Nairobi, Kenya, May 22-24.

Obioha, Emeka E. 2020. Affordable Housing in Addressing Homelessness in Sub-Sahara Africa: Highlights and Good Practices. Paper presented at the High-Level Panel Discussion on the Priority Theme: "Affordable Housing and Social Protection Systems for all to Address Homelessness", New York, NY, USA, January 10-19.

Open DRI. 2018. Tackling Coastal Flooding in Monrovia Slums: Understanding through Partnerships, One Community at a Time. Available online: https:/ / opendri.org/tackling-coastal-flooding-in-monrovia-slums/ (accessed on 5 February 2020).

Pottie, David. 2004. Local government and housing in South Africa: Managing demand and enabling markets. Development in Practice 14: 606-18. [CrossRef]

Racelma, Kaci. 2012. Towards African Cities without Slums. UN/African Renewal. Available online: https://www.un.org/ africarenewal/magazine/april-2012/towards-african-cities-without-slums (accessed on 24 July 2021).

Relief Web. 2004. Namibia Floods Leave Thousands Homeless. British Red Cross. Available online: https://reliefweb.int/report/ namibia/namibia-floods-leave-thousands-homeless (accessed on 25 January 2020). 
Relief Web/(UNOCHA UN) Office for the Coordination of Humanitarian Affairs. 2019. Cameroon: North-West and South-West Situation Report No. 3, 2019. United Nations. Available online: https:/ /reliefweb.int/report/cameroon/cameroon-north-westand-south-west-crisis-situation-report-no-3-31-january-2019 (accessed on 25 January 2020).

Sisson, Alistair, and Dallas Rogers. 2020. Housing. International Encyclopaedia of Human Geography 7: 69-73. [CrossRef]

South World. 2018. Mali. In Helping the Street Children of Bamako. London: South World, Available online: https://www.southworld. net/mali-helping-the-street-children-of-bamako/ (accessed on 25 January 2020).

The Sun. 2018. Addressing Nigeria's housing challenge [Editorial]. In The Sun. Lagos: Sun Newspaper Company, Available online: https: / / www.sunnewsonline.com/addressing-nigerias-housing-challenge/ (accessed on 20 January 2020).

UNCHR. 2008. 2007 Global Trends: Refugees, Asylum-Seekers, Returnees, Internally Displaced and Stateless Persons. Available online: https: / / www.unhcr.org/statistics/STATISTICS/4852366f2.pdf (accessed on 5 February 2020).

UNHabitat. 2011. Affordable Land and Housing in Asia. Available online: https://unhabitat.org/wpdm-package/affordable-landand-housing-in-asia/?wpdmdl=111395 (accessed on 20 January 2020).

United Nations. 1948. Universal Declaration of Human Rights. Palais de Chaillot, Paris: United Nations, Available online: https: //www.un.org/sites/un2.un.org/ files/udhr.pdf (accessed on 16 August 2021).

United Nations. 2004. United Nations Demographic Yearbook Review. New York: United Nations, Department of Economic and Social Affairs, Statistics Division, Demographic and Social Statistics Branch.

United Nations/Department of Social and Economic Affairs. 2015. Millennium Development Goals Indicators. Available online: http:/ / mdgs.un.org/unsd/mdg/Data.aspx (accessed on 25 January 2020).

World Bank. 2018. Population Living in Slums (Percentage of Urban Population). Available online: https://data.worldbank. org /indicator /EN.POP.SLUM.UR.ZS?end=2018\&most_recent_year_desc=false\&start=1990\&view=chart (accessed on 25 January 2020).

World Economic Forum. 2019. Making Affordable Housing a Reality in Cities. Geneva: World Economic Forum, Available online: http: //www3.weforum.org/docs/WEF_Making_Affordable_Housing_A_Reality_In_Cities_report.pdf (accessed on 5 February 2020). 